\title{
Foraminifera biostratigraphy and paleoenvironment of Well 5, OML 34, Niger Delta, Nigeria
}

\author{
Emmanuel C. Nwaejije, Enam O. Obiosio, and Ibrahim Hamidu
}

\begin{abstract}
A full account of 67 ditch cutting samples collected from Well 5, OML 34 in the Niger Delta at depth intervals between $2441 \mathrm{~m}$ to $3650 \mathrm{~m}$ is presented. Lithologic description of the samples shows seven lithostratigraphic units composed of shale, siltstone and sandstone corresponding to the Paralic Agbada Formation. Foraminifera analysis was carried out on these samples, a total of 51 species were recovered; 37 benthonic and 14 planktonic. The planktonic index recovered from the well, Praeorbulina glomerosa, Praeorbulina sicana, Orbulina saturalis, and Catapsydrax dissimilis, revealed that the age of the penetrated well is Miocene. Three planktonic foraminifera zones corresponding to Blow, 1969 (N6 - N7, N8 - N9 and N9) and Berggren et al., 1995 (M4, M4 - M5, and M5) zones are proposed for the well. The planktonic zones are Catapsydrax dissimilis Partial-range zone, Praeorbulina glomerosa Interval zone, and Orbulina universa Taxon - range zone, respectively. Sediments of the well are considered to be of normal marine depositional environment based on shell type ratio and triangular plot of the foraminifera test type (arenaceous, porcelaneous and hyaline). The paleobathymetry of the well ranges from non-marine to middle neritic environment based on foraminifera distribution.
\end{abstract}

Emmanuel C. Nwaejije. Department of Geology, Ahmadu Bello University, Zaria, Nigeria. emmanuelcelestine01.ec@gmail.com

Enam O. Obiosio. Department of Geology, Ahmadu Bello University, Zaria, Nigeria.

eoobiosio@abu.edu.ng

Ibrahim Hamidu. Department of Geology, Ahmadu Bello University, Zaria, Nigeria. hibrahim@abu.edu.ng

Keywords: biostratigraphy; lithostratigraphy; paleoenvironment; foraminifera; Niger Delta

Submission: 19 January 2016 Acceptance: 6 October 2017

Nwaejije, Emmanuel C., Obiosio, Enam O., and Hamidu, Ibrahim. 2017. Foraminifera biostratigraphy and paleoenvironment of Well 5 , OML 34, Niger Delta, Nigeria. Palaeontologia Electronica 20.3.51A: 1-17. https://doi.org/10.26879/630

palaeo-electronica.org/content/2017/2036-foraminifera-in-niger-delta

Copyright: October 2017 Palaeontology Association.

This is an open access article distributed under the terms of Attribution-NonCommercial-ShareAlike 4.0 International (CC BY-NC-SA 4.0 ), which permits users to copy and redistribute the material in any medium or format, provided it is not used for commercial purposes and the original author and source are credited, with indications if any changes are made.

creativecommons.org/licenses/by-nc-sa/4.0/creativecommons.org/licenses/by-nc-sa/4.0/ 


\section{INTRODUCTION}

According to Evamy et al. (1978) and Reijers et al. (1997), the petroleum industry in Nigeria have described and adopted informal biostratigraphic zonations, which are largely unpublished. This lack of formal biostratigraphic zonations for the Niger Delta still persists even though foraminifera biostratigraphy of several wells from the Niger Delta have been extensively published (Petters, 1979, 1982, 1983; Adeniran, 1997; Ozumba and Amajor, 1999; Oluwatosin, 2010; Okosun et al., 2012; Obiosio, 2013; Oloto and Promise, 2014), however, the foraminiferal biostratigraphy of Well 5 OML 34 has not been documented.

Attempts to mutually validate and integrate the Shell Petroleum Development Company (SPDC) framework of Evamy et al. (1978) with published and unpublished works of other industry groups is hampered by the use of different alphanumerical coding systems for the foraminifera systematics. However, Reijers et al. (1997) reported that there have been concerted efforts within the scope of the stratigraphic committee of the Niger Delta (STRATCOM), to produce a generally acceptable delta-wide biostratigraphic framework, but not much has been accomplished after several data gathering exercises by the committee.
This study carried out a detailed biostratigraphic description of Well 5 OML 34, (Figure 1) in order to propose biozones and paleoenvironments for the well.

\section{Geology of the Niger Delta}

The Niger Delta is an oil province of Nigeria located on the West African Continental margin. The Niger Delta basin lies between latitude $4^{\circ} 00^{\prime} 00^{\prime \prime} \mathrm{N}$ and $6^{\circ} 00^{\prime} 00^{\prime \prime} \mathrm{N}$ and longitude $5^{\circ} 00^{\prime} 00^{\prime \prime} \mathrm{E}$ and $8^{\circ} 00^{\prime} 00 " \mathrm{E}$. It is bounded to the west and northwest by the Western African shield, which terminates at the Benin hinge line and to the east, by the Calabar hinge line. The Anambra basin and Abakaliki anticlinorium mark its northern limit. To the south, it is bounded by the Gulf of Guinea. The Niger Delta is a large arcuate delta of the destructive, wave-dominated type and is composed of an overall regressive clastic sequence, which reaches a maximum thickness of about $12 \mathrm{~km}$ in the basin centre. The shape and internal structure of the Niger Delta are controlled by fracture zones along the oceanic crust, such as the Charcot fracture zone, Chain fracture zone, and the Romanche fracture zone (Corredor et al., 2005).

The Niger delta is characterized by three formations that range in age from early Tertiary to Recent, showing an overall upward transition from

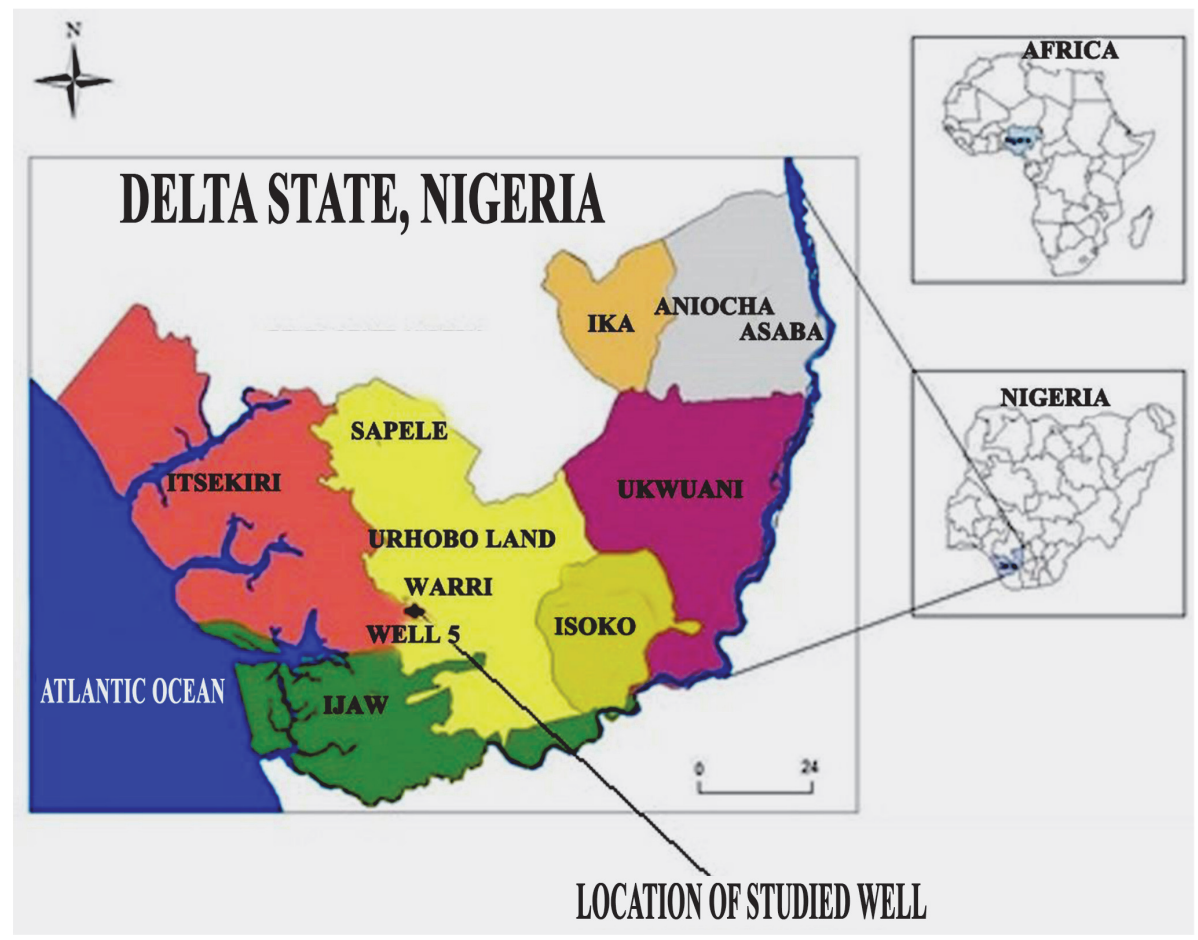

FIGURE 1. Location of studied well (modified after Odemerho; Urhobo Historical Society, 2008). 
marine prodelta shales (Akata Formation) through sand-shale paralic sequence (Agbada Formation) to continental sands and gravels (Benin Formation; Short and Stauble, 1967; Avbovbo, 1978). Murat (1972) described the three formations as being strongly diachronous, implying that the formations transit through several geologic time intervals.

\section{METHODS}

Biostratigraphic analysis was carried out on 67 ditch cutting samples obtained from Well 5, OML 34, Niger Delta. Samples were collected at $18 \mathrm{~m}$ (60ft) interval with a total thickness of $1200 \mathrm{~m}$. The procedure of analysis is as follows:

1. Lithostratigraphic analysis was carried out on the samples by visual inspection. Physical characteristics such as colour, texture, hardness, fissility, and rock type were noted taking into consideration published lithofacies description of the Niger Delta as well as lithofacies models of Webber and Daukoru (1975) and Whiteman (1982). Chemical test to determine the presence of calcareous materials was also carried out using $10 \%$ dilute $\mathrm{HCl}$.

2. Biostratigraphic Studies: The procedures adopted for the microfossil extraction is in line with standard micropaleontological sample preparation technique (Pessagno, 1967; Zingula, 1968; Brasier, 1980). Ditch cuttings from the well were prepared for lithostratigraphic description and micropaleontologic analysis at $18 \mathrm{~m}(60 \mathrm{ft})$ intervals. The procedure is outlined as follows:

3. Prepared sample list, washed samples free from drilling mud and allowed to dry, treated a quantity $(200 \mathrm{~g})$ with one teaspoonful of anhydrous sodium carbonate for thorough disintegration, added enough water to cover the samples and allow to stand for few hours, washed the soaked sample using a $63 \mu$ (230mesh), sieve, dried the washed sample at a minimum temperature of $20^{\circ} \mathrm{C}$, decanted the dried sample into coarse, medium and fine fractions, stored samples in well labeled sample bags.

4. In carrying out the detailed procedure outlined above, care was taken to avoid contamination with other samples.

5. All size fractions were examined individually on a picking tray, the grid lines in the tray helped to ensure that all parts of the tray was well observed. Foraminifera was picked with the aid of a sable brush 000 under a binocular microscope.

6. The various foraminifera taxa encountered in each sample during the picking exercise were grouped and mounted temporarily with gum on a micropaleontological slide cavity and covered with a cover slip. These slides were arranged serially for identification. The identification of the various foraminifera was done largely by comparison with forms that have been previously described by Sellier de Civrieux (1976), Petters (1982), Loeblich and Tappan (1987), and Bolli and Saunders (1985).

Biostratigraphic data yielded biofacies information for paleoenvironment and bathymetry. Dating of the key surfaces where possible was achieved by their calibration to the third order cycles of Haq et al. (1988).

Photomicrographs of foraminifera recovered from the studied well were taken using a Celestron $5 \mathrm{mp}$ digital camera, mounted on a binocular microscope.

\section{RESULTS}

\section{Lithostratigraphic Units}

The lithostratigraphic section of the well is based on ditch cutting samples described and information gathered from wire line log. The thickness of analyzed well is $1209 \mathrm{~m}$ (2441- $3650 \mathrm{~m}$ interval). The lithologies are mainly sandstone, shale and siltstone, and the lithostratigraphic section revealed 7 distinct lithologic units (Figure 2).

\section{Foraminifera Fauna}

Foraminifera analysis was carried out on 67 samples obtained from the well (interval 2441$3650 \mathrm{~m}$ ). The foraminifera recovery was fair, the diversity, however, was high. The forms encountered include planktonic foraminifera, benthonic calcareous foraminifera, and also benthonic arenaceous foraminifera.

Planktonic foraminifera. Fourteen planktonic foraminifera species were recovered (Table 1, Appendix 1), which constitutes about $28 \%$ of the foraminifera population. The planktonic foraminifera are dominated by species of: Globigerina sp., Orbulina suturalis, Praeorbulina glomerosa, Globorotalia mayeri, and Planktic indet sp. Other important planktonic foraminifera species recovered include Catapsydrax dissimilis and Praeorbulina sicana. 


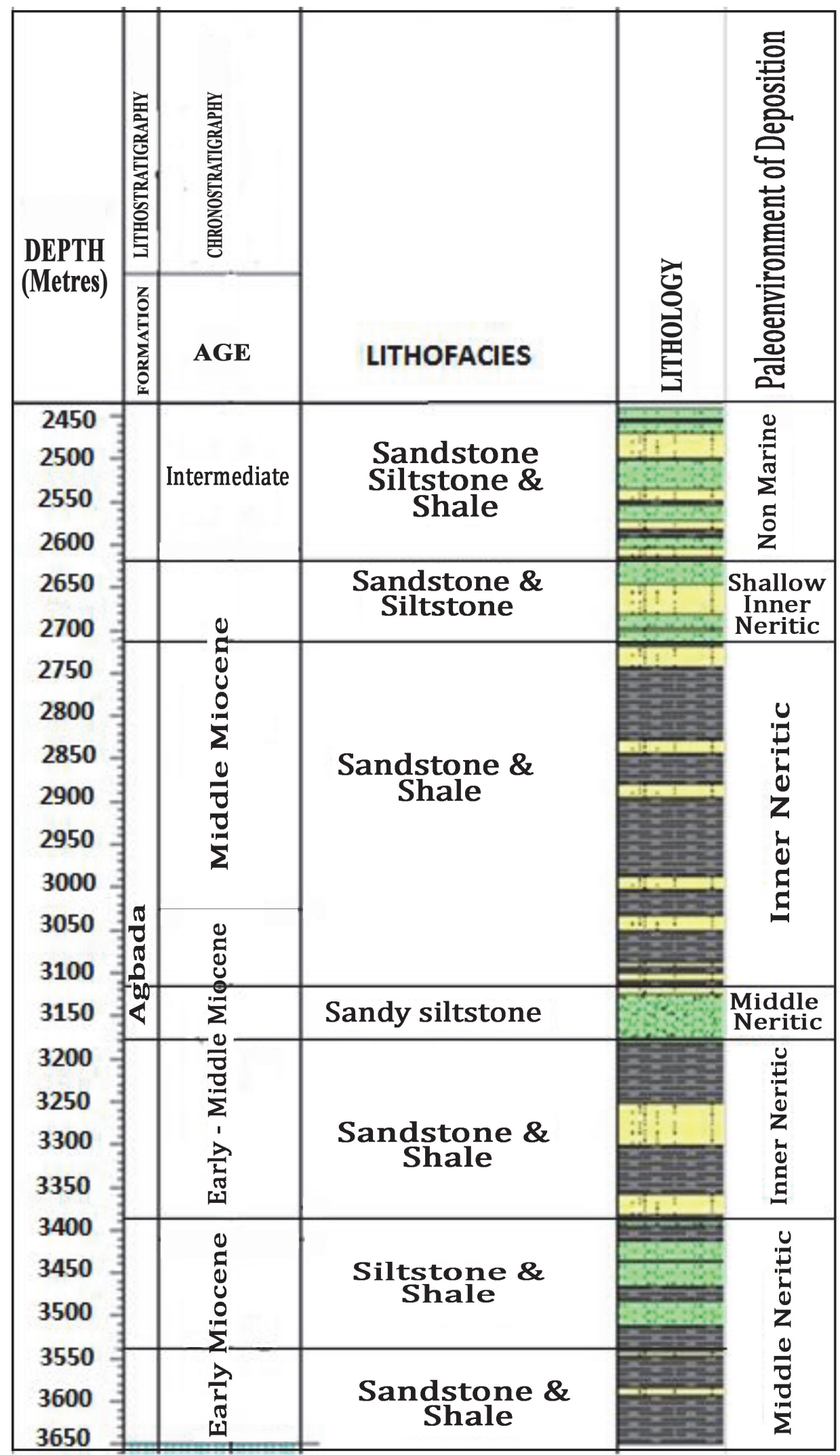

FIGURE 2. Lithostratigraphic section of Well 5 OML 34. 
TABLE 1. Planktonic foraminifera total count.

\begin{tabular}{lc}
\hline $\begin{array}{c}\text { Arenaceous Assemblage } \\
\text { (FOBA) }\end{array}$ & Total Count \\
\hline Ammobaculites sp. & 1 \\
Spiroplectammina sp. & 2 \\
Haplophragmoides sp. & 3 \\
Textularia laminata & 1 \\
Textularia panamensis & 1 \\
Spiroplectammina wrightii & 1 \\
Total & 9 \\
\hline
\end{tabular}

Benthonic foraminifera. The benthonic foraminifera species in the well are made up of diverse and rich to occasionally abundant species. Preservation is fairly good all through the section. Thirty seven benthonic species was recovered, accounting for about $72 \%$ of the total foraminifera population, thirty-one calcareous species (Table 2, Appendix 2) and six that make up the benthonic arenaceous species (Table 3, Appendix 2). The benthonic foraminifera are dominated by species of: Uvigerina isidroensis, Brizalina mandoroveensis, Lenticulina grandis, Hopkinsina bononiensis, Hanzawaia stratonii, Ammonia beccarii, Heterolepa floridana, Cibicorbis inflata, Uvigerina sp.Valvulineria gasparensis, Haptophragmoides sp., and Spiroplectammina sp. Some of the other species have poor occurrences to single occurrences as in the case of Textularia laminata, Ammobaculites sp., Bolivina spinata.

\section{DISCUSSION}

\section{Lithostratigraphy}

The lithology (Figure 2) shows siltstone layers with the alternation of sandstone and shale, the shale is brown to grey, occasionally black to brown, moderately hard. The sandstone is fine-grained (occasionally coarse-grained), sub-angular to subrounded, well sorted and occasionally ferruginized. Figure 2 shows an alternation of sandstone with shale, suggesting that the studied well interval $(2441-3650 \mathrm{~m})$ penetrated the Agbada Formation of the Niger Delta. In general, it has been observed that the upper part of the formation has a higher sandstone percentage than the lower part, suggesting progressive, seaward advancement of the Niger delta through geological time.

\section{Age Determination}

Planktonic foraminifera are a microfossil group that play a vital role in biostratigraphic subdi-
TABLE 2. Benthonic calcareous foraminifera total count.

\begin{tabular}{|c|c|}
\hline $\begin{array}{l}\text { Calcareous Assemblage } \\
\text { (FOBC) }\end{array}$ & Total Count \\
\hline Ammonia beccarii & 14 \\
\hline Hanzawaia stratonii & 21 \\
\hline Lenticulina grandis & 36 \\
\hline Uvigerina isidroensis & 97 \\
\hline Brizelina interjuncta & 8 \\
\hline Heterolepa floridana & 18 \\
\hline Quinqueloculina sp. & 6 \\
\hline Uvigerina sp. & 13 \\
\hline Valvulineria gasparensis & 10 \\
\hline Eponides eshira & 8 \\
\hline Hopkinsina bononiensis & 33 \\
\hline Lenticulina inornata & 3 \\
\hline Quinqueloculina lamarckiana & 1 \\
\hline Myogypsinoides sp. & 5 \\
\hline Quinqueloculina microcostata & 2 \\
\hline Uvigerina sparsicostata & 8 \\
\hline Bolivina sp. & 2 \\
\hline Bulimina sp. & 2 \\
\hline Hanzawaia concentrica & 1 \\
\hline Heterolepa pseudoungeriana & 5 \\
\hline Bolivina dilatata & 1 \\
\hline Epistominella vitrea & 2 \\
\hline Uvigerina topilensis & 3 \\
\hline Cibicorbis inflata & 14 \\
\hline Eponides ornatus & 2 \\
\hline Gavelinella aff. beninensis & 1 \\
\hline Quinqueloculina seminulum & 1 \\
\hline Bolivina spinata & 1 \\
\hline Brizalina mandoroveensis & 59 \\
\hline Epistominella potoni & 7 \\
\hline Florilus atlanticus & 2 \\
\hline Total & 386 \\
\hline
\end{tabular}

visions and correlation of deep sea cores, hence, the importance of some planktonic foraminifera as index fossils have become increasingly recognized. Their abundance in marine sediments combined with the short life span of many species makes the planktonic foraminifera better suitable for time stratigraphic correlations, this is largely due to their wide geographical distribution combined with additional dispersal by ocean currents which makes them valuable index fossils for worldwide stratigraphic correlation.

The following index forms were identified: Praeorbulina glomerosa, Praeorbulina sicana, 
TABLE 3. Benthonic arenaceous foraminifera total count.

\begin{tabular}{lc}
\hline \multicolumn{1}{c}{ Foraminifera Assemblage } & Total count \\
\hline Globigerina sp. & 5 \\
Globigerina venezuelana & 2 \\
Orbulina universa & 2 \\
Planktic indet sp. & 3 \\
Globorotalia continuosa & 3 \\
Praeorbulina glomerosa & 3 \\
Praeorbulina sicana & 2 \\
Orbulina saturalis & 4 \\
Globigerinoides immaturus & 2 \\
Globigerinoides sacculifer & 1 \\
Globigerinoides trilobus & 2 \\
Globigerinoides quadrilobatus & 1 \\
Catapsydrax dissimilis & 1 \\
Globigerinoides sp & 1 \\
Total & 32 \\
\hline
\end{tabular}

Orbulina saturalis, and Catapsydrax dissimilis. Based on the presence of these index forms, as defined by Bolli and Saunders (1985) and Petters (1983), the age of the studied well ranges from Early Miocene to Middle Miocene.

Early Miocene. The upper limit of the Early Miocene in the study well interval is marked at $3411 \mathrm{~m}$ based on the last downhole occurrence (LDO) of Praeorbulina glomerosa and the lower limit is marked at $3648 \mathrm{~m}$ based on the first downhole occurrence (FDO) of Catapsydrax dissimilis. This interval is characterized by the presence of Early Miocene planktonics (Globigerinoides quadrilobatus).

Early - Middle Miocene. The upper limit is marked at $3027 \mathrm{~m}$ based on the last downhole occurrence (LDO) of Orbulina universa and the lower limit is marked at $3374 \mathrm{~m}$ based on the last downhole occurrence (LDO) of both Orbulina saturalis and Praeorbulina glomerosa. Other planktonic forms present include Globigerinoides trilobus, Globigerinoides quadrilobatus, and Globigerinoides sacculifer.

Middle Miocene. The upper limit of the Middle Miocene is indeterminate in the sequence studied because of the absence of marker species, the lower limit, however, is marked at $3027 \mathrm{~m}$ based on the last downhole occurrence (LDO) of Orbulina universa. Other planktonic forms present include Praeorbulina sicana, Globigerina sp., Globigerina venezuelana, and Globorotalia mayeri.

\section{Biozonation}

Three zones have been proposed in this study, based on the International stratigraphic guide of Hedberg (1976) and the observation of the ranges of planktonic foraminifera (Figure 3 ) as follows: Catapsydrax dissimilis partial-range zone, Praeorbulina glomerosa interval zone and Orbulina universa taxon-range zone.

Catapsydrax dissimilis partial-range zone. Stratigraphic interval: $3648-3411 \mathrm{~m}$

The zone is defined by the first downhole occurrence (FDO) of Catapsydrax dissimilis and Globigerinoides sp. at the base and the last downhole occurrence (LDO) of Praeorbulina glomerosa at the top (Figure 3). Other planktonic forms occurring within the zone are Globigerinoides sp. Globigerinoides quadrilobatus, Planktic indet sp. and Globorotalia mayeri. This zone is equivalent to M4 zone of Berggren et al. (1995) and the N6 - N7 zone of Blow (1969). The FDO of Catapsydrax dissimilis marks the M4 and N6/N7 boundaries of Berggren et al. (1995) and Blow (1969), respectively. Catapsydrax dissimilis is continuously present in the Early Miocene. The age of this zone is Early Miocene based on the presence of planktonic index forms.

Praeorbulina glomerosa interval zone. Stratigraphic interval: $3411-3027 \mathrm{~m}$

The zone is defined by the LDO of Praeorbulina glomerosa at the base and the LDOs of Praeorbulina sicana and Orbulina universa at the top (Figure 3). Other planktonic forms occurring in this zone are Globigerinoides immaturus, Globigerinoides sacculifer, Globigerinoides trilobus, and Orbulina suturalis. This zone corresponds to the M4 M5 and N8 - N9 zones of Berggren et al (1995) and Blow (1969) respectively. The zone is dated Early to Middle Miocene based on the presence of planktonic index forms.

Orbulina universa taxon - range zone. Stratigraphic interval: $3027-2760 \mathrm{~m}$.

This zone is defined by the entire occurrence of Orbulina universa. The base of the zone is marked by the LDO of Orbulina universa, and Praeorbulina sicana, respectively, while the top is marked by the FDO of Orbulina universa, Globigerina venezuelana, and Planktic indet sp., respectively (Figure 3). Other planktonic forms occurring in the zone are Globigerina sp. Globigerina venezuelana, Globorotalia mayeri, Praeorbulina glomerosa and Praeorbulina sicana. The zone is equivalent to the M5 and N9 zones of Berggren et al. (1995) and Blow (1969), respectively. The zone 


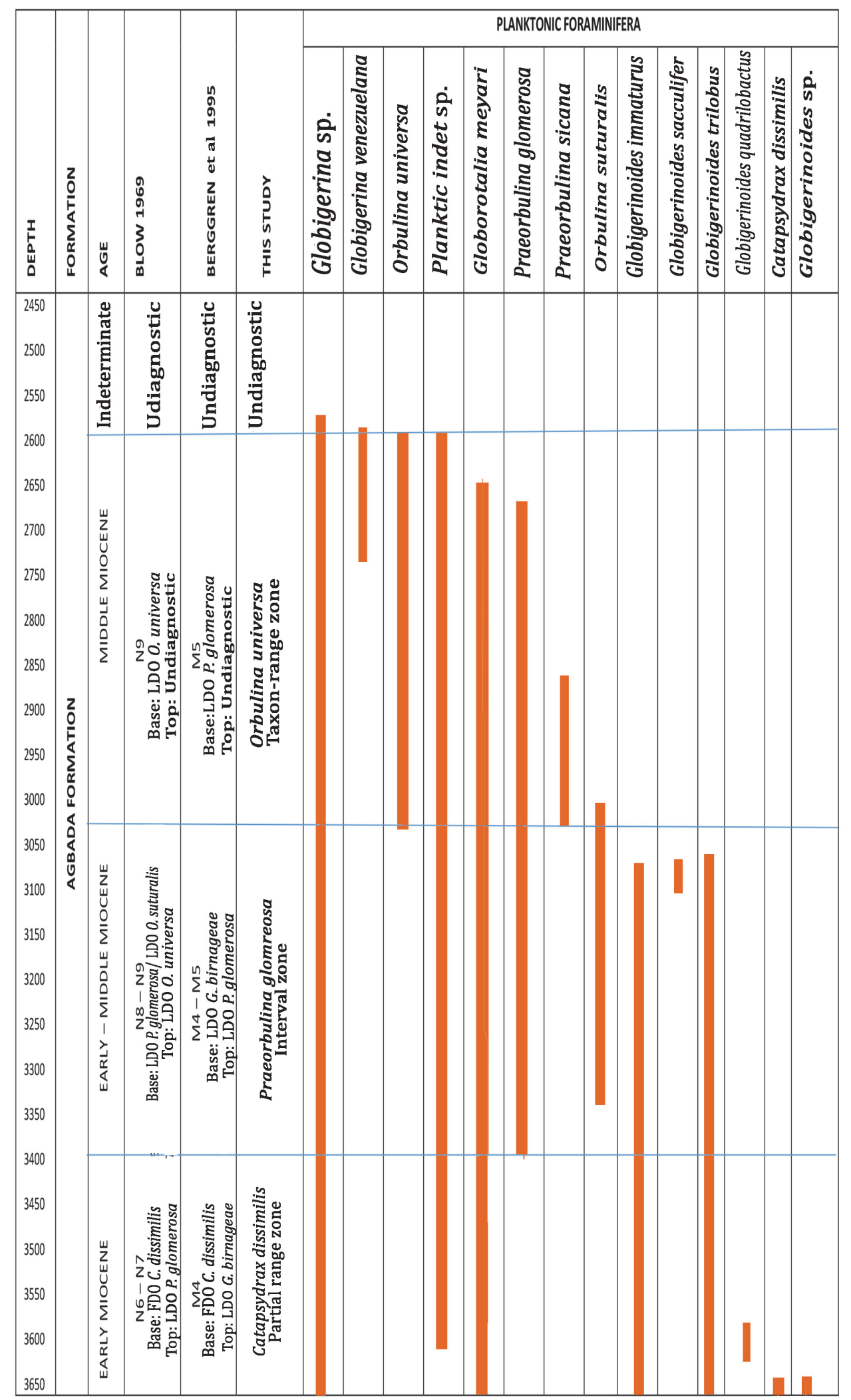

FIGURE 3. Ranges of planktonic foraminifera showing biozones for the studied Well 5. 
is dated Middle Miocene based on the presence of planktonic index forms.

The planktonic foraminiferal preservation in the upper intervals of the well is poor. Stratigraphically important taxa (planktonic index forms) were not identifiable, therefore the undiagnosed stratigraphic interval above the Orbulina universa taxon - range zone is assumed to be M6 zone of Berggren et al (1995) and N9/N10 zone of Blow (1969), because of the stratigraphic position above the positively identified zone (Orbulina universa taxon - range zone). The age is assumed to be Middle Miocene for the same reason.

\section{Paleoenvironment}

Following the same principles as Bandy (1964), Funnel (1967), Boersma (1978), and Brasier (1980), the paleodepositional environment of the studied well was established based on the information interpreted from the evaluation of the benthonic foraminifera assemblages. This has been integrated with the lithologic description of the well and the planktonic/benthonic foraminifera ratio.

\section{Paleobathymetry}

Foraminifera data was most useful in the estimation of paleobathymetry, it involved the use of relative abundance and diversity of the foraminifera encountered as well as the occurrence of environmentally significant taxa. It is on these bases that the sediments of the well were interpreted to have fluctuated from non-marine to middle neritic as follows:

- Middle Neritic Environment

- Inner Neritic Environment

- Shallow Inner Neritic Environment

- Non marine Environment

The well interval possessed characteristics that are exhibited by the above environments.

Non marine environment (Figure 4). This inference is based on the following reasons:

1. The intervals are characterized by fine grained sandstone, siltstone, and shale. The presence of fine grained sandstone and carbonaceous detritus in these intervals suggests deposition in low energy environment, probably near-shore settings, and this condition is evident of paralic environments and reflects a marine transgression (Oboh-lkuenobe et al., 2005).

2. The intervals are completely barren of foraminifera. The complete absence of fauna in this interval suggest a littoral (shore or coastal) settings.

Shallow inner neritic environment (Figure 4). This inference is based on the following reasons:

1. The intervals are characterized by medium to coarse grained sand (with very thin shale beds), suggesting deposition during progradational phase. The presence of coarse sandstone, ferruginous materials, and carbonaceous detritus in these intervals indicates deposition in high energy, probably near-shore settings.

2. The intervals contain very few benthonic and planktonic foraminifera (e.g., Ammobaculites sp., Valvullineria gasparensis and Globigerina sp.). Species abundance is low, and the number of species (diversity) is high. The planktonic types constitute from $20-30 \%$ of the total fauna, (Boersma, 1978).

Inner neritic environment (Figure 4). This inference is based on the following criteria:

1. The microfauna found here suggest inner neritic environmental settings with middle neritic influence, these include: Quinqueloculina sp. Lenticulina grandis, Uvigerina sp. Miogypsinoides sp. Cubicubis inflata, Brizaliana mandoreveensis, Spiroplectammina wrightii, Uvigerina isidroensis, and Uvigerina sparsicostata. The diversity range from zero to nine species.

2. The lithology of the intervals is composed of medium to coarse grained sand (smoky white to orange, sub-angular to sub-rounded, wellsorted and occasionally ferruginized), siltstone (white, fine-grained, micromicaceous, and carbonaceous plus traces of woody materials), and shale (brown to grey, fissile, moderately hard, micromicaceous, and occasionally carbonaceous).

Inner to middle neritic environment. This environment of the studied well (Figure 4) is inferred based on the following:

1. The occurrence of the typical forms from inner and middle neritic environments, including: Uvigerina sp. Heterolepa floridana, Valvulineria gasparensis, Cibicorbis inflata, Orbulina suturalis, Hanzawaia stratonii, Globigerinoides immaturus, Globigerinoides sacculifer, Globigerinoides trilobus, Hanzawaia concentrica, Hopkinsina bononiensis, and Spiroplectammina wrightii. The population of planktonics foraminifera increases as well as 


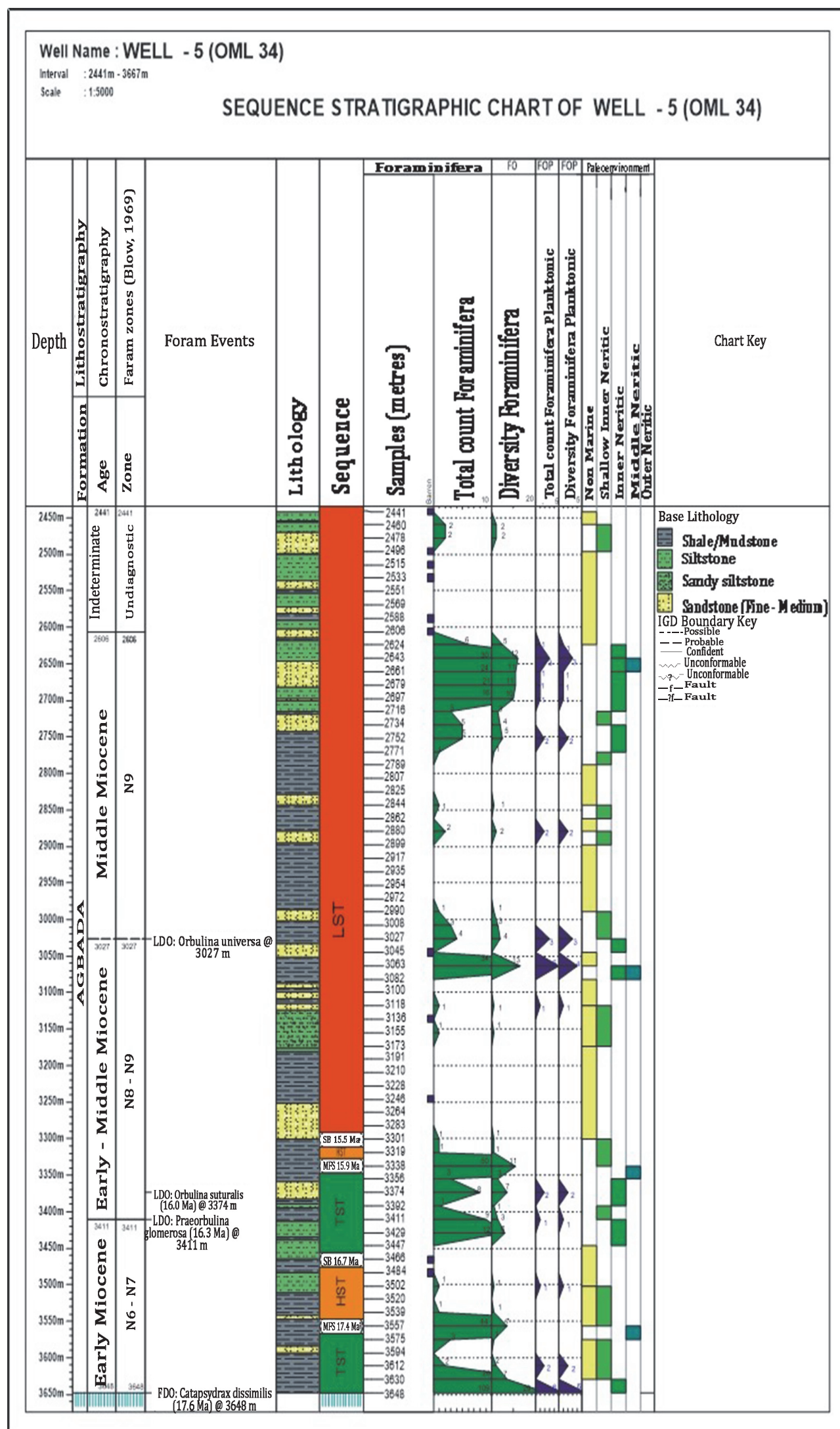

FIGURE 4. Sequence Stratigraphy chart showing paleobathymetry of deposition of studied well. 
the species diversity (ranging from zero to 20 species).

2. The lithology is composed of sand (smoky white to orange, sub-angular to sub-rounded, well-sorted, and occasionally ferruginized), siltstone (white, fine-grained, micromicaceous and carbonaceous plus traces of woody materials), and shale (brown to grey, fissile, moderately hard, micromicaceous, and occasionally carbonaceous).

According to Okosun et al. (2012), the inner to middle neritic environment is characterized by the occurrence of the typical forms from inner, middle, and outer neritic environments like Uvigerina sp, Spiroplectamina wrightii, and Hanzawaia strattoni. Middle neritic environment. This environment (Figure 4) is inferred based on the following characteristics:

1. The presence of indicator fauna like: Lenticulina inornata, Heterolepa pseudoungeriana, Lenticulina grandis, Uvigerina isidroensis, Brizalina mandoroveensis, Valvullineria gasparensis, Globigerina sp., Globigerina venezuelana, Orbulina universa, Globorotalia continuosa, Panktic indet sp., and Praeorbulina glomerosa. There is an increase in the number of planktonic specimens. The average planktonic/benthonic ratio is high, the simple species diversity also increased, ranging from zero to 23 species.

2. The lithology is composed of siltstone (white, fine-grained, micromicaceous, and carbonaceous plus traces of woody materials) and shale (brown to grey, fissile, moderately hard, micromicaceous, and occasionally carbonaceous).

This environment is recognized by the presence of indicator fauna like, Lenticulina inornata, and Heterolepa pseudougerina. Increase in the number of planktonic specimens. The average planktonic/benthonic ratio is high, the sample species diversity is also increased and the lithology of the middle neritic environment is composed of shale and silt (Okosun et al., 2012).

The occurrence of shell fragments, ostracods, gastropods, along with the occurrence of Textularina $\mathrm{sp}$. suggest a shallow marine origin, the presence of Textularina laminata, Textularina panamensis, and Ammobaculites sp. suggest inner shelf environment of deposition (Nton and Esan, 2010).

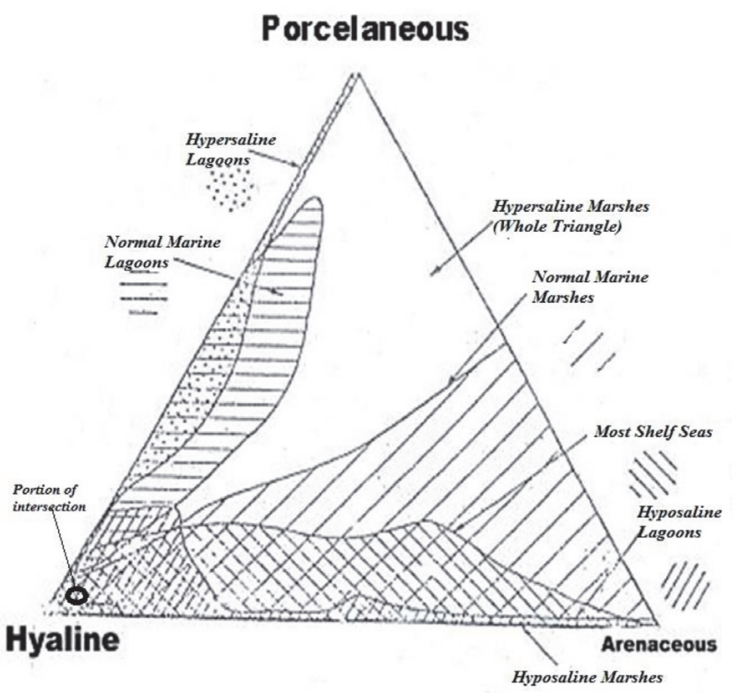

FIGURE 5. Triangular plot of shell-type ratio, showing portion of intersection as normal marine shelf sea environment (Modified after Murray, 1973).

Based on the paleoenvironmental interpretation provided above, it can be inferred that the paleobathymetry of the study well ranges from shallow to inner shelf environment.

\section{Paleosalinity}

Foraminifera live in all marine environments from the deepest ocean floor to the intertidal salt marshes found behind barrier islands or around the margins of estuaries.

Paleosalinity interpretations for the studied well were made based on Shell-type (morphogroup) ratio triangular plot (Figure 5 ). The proportion of the three shell type (agglutinated, hyaline, and porcelaneous; Figure 6) of foraminifera in a sample can be used to characterize a particular environment in seas and oceans.

The triangular plot above reveals the dominance of the hyaline calcareous shell type suggesting a normal marine shelf sea environment. Comparison with modern micro fauna suggests a normal marine neritic environment (Murray, 1973, 1991).

The dominance of the calcareous benthonics (FOBC) with over $60 \%$ of total forms present suggests an open marine condition (Nagy et al., 1988).

According to Murray (1991) and Sen Gupta (1999), the high diversity and dominance of calcareous taxa suggests transition from brackish marginal marine habitats to open neritic conditions. 


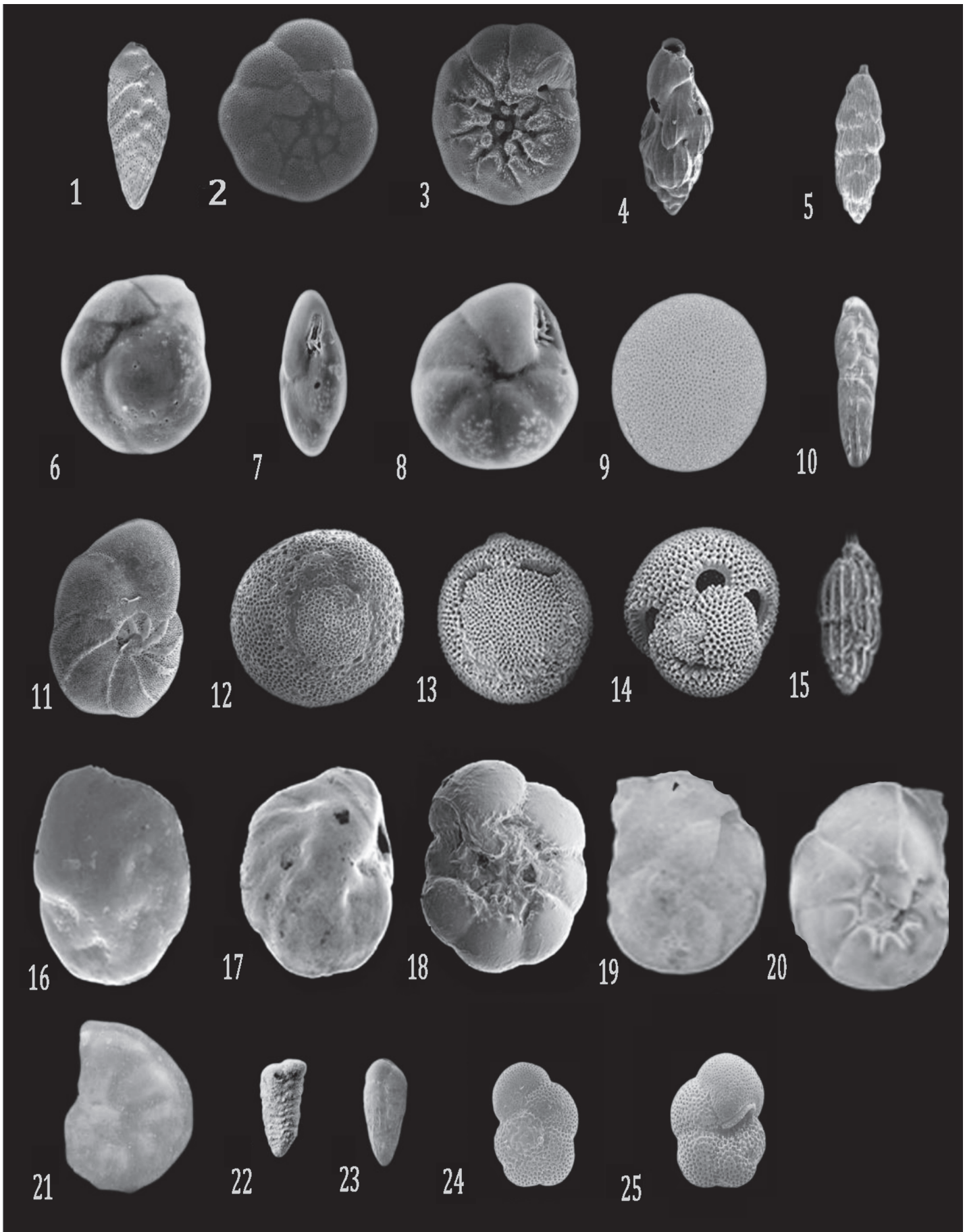

FIGURE 6. Photomicrographic plate of some foraminfera specie from the studied well. 1, Bolivina dilatata, (Reuss) $X$ 100; 2-3, Ammonia beccarii (Linne), (2)Dorsal view X 200, (3) Ventral view X 200; 4, Uvigerina sp. (Cushman) X 150; 5, Hopkinsina bononiensis, (Fornasini) X 150; 6-8, Epistominella vitrea(Parker), (6) Dorsal viewX 200, (7) Edge view X 200, (8) Ventral view X 200; 9, Orbulina universa, (d'Orbigny) X 250; 10, Brizalina interjuncta, (Graham, De Klasz and Rerat) X 150; 11, Heterolepa floridana, (Cushman) X 200; 12, Orbulina suturalis, (Bronnimann) X 250; 13, Praeorbulina glomerosa, (Blow) X 200; 14, Praeorbulina sicana, (Cushman and Stainforth) X 200; 15, Uvigerina isidroensis, (Cushman and Renz) X 150; 16-17, Cibicorbis inflata, (d'Orbigny), (16) Dorsal view X 200, (17) Ventral view X 200; 18, Hanzawaia strattonii, (Applin) X 200; 19-20,Valvulineria gasperensis, (Bermudez) (19) Dorsal view X 200, (20) Ventral view X 200; 21, Lenticulina grandis,(Cushman) X 200; 22, Textularia laminata, (Cushman) X 100; 23, Brizalina mandoroviensis, (Graham) X 100; 24-25, Globorotalia mayeri, (Cushman and Ellisor) (24) Dorsal view X 200, (25) Ventral view X 200. 


\section{CONCLUSION}

Based on the lithology and foraminifera recovered from the well, it is inferred that the well penetrated the Agbada Formation and is of Miocene age (Early and Middle Miocene).

Three planktonic foraminifera zones: Catapsydrax dissimilis Partial-range zone, Praeorbulina glomerosa Interval zone, and Orbulina universa Taxon - range zone corresponding to Berggren et al. 1995 (M4, M4 - M5, and M5) and Blow 1969 (N6 - N7, N8 - N9 and N9) zones, respectively, have been proposed for the well. It is hoped that the three biozones proposed in this study will contribute to the findings of the stratigraphic committee of the Niger Delta (STRATCOM), to produce a generally acceptable delta-wide biostratigraphic framework.

The observed lithology and foraminifera assemblages especially the benthonics indicated that the sediments of the well were deposited in a non-marine to shallow inner neritic, inner neritic, inner to middle neritic, and middle neritic environments.

Further study of data sets from adjoining wells in the region will help in proper correlation of the zones, boundaries, and depositional environment in the study area.

\section{ACKNOWLEDGEMENTS}

The authors wish to acknowledge Shell Petroleum Development Company of Nigeria (SPDC) for providing ditch cutting samples used in this study. We also acknowledge the reviewers who took time to review and make amendments to improve this paper.

\section{REFERENCES}

Adeniran, B.V. 1997. Quantitative Neogeneplanktic foraminiferal biostratigraphy of Western Niger Delta, Nigeria. Nigerian Association of Petroleum Explorationists Bulletin, 12:54-59.

Avbovbo, A.A. 1978. Tertiary lithostratigraphy of Niger Delta. American Association of Petroleum Geologists Bulletin, 62:295-300.

Bandy, O.L. 1964. Cenozoic planktonic foraminifera zonation. Micropaleontology, 10:1-17.

Berggren, W.A., Kent, D.V., Swisher, III, C.C., and Aubry, M.-P. 1995. A revised Cenozoicgeochronology and chronostratigraphy, p. 129-212. In Berggren, W.A., Kent, D.V., Aubry, M.-P., and Hardenbol, J. (eds.), Geochronology, Timescales and Global Stratigraphic Correlation.Tulsa SEPM Special Publication 54.

Blow, W.H. 1969.Late Middle Eocene to Recent Planktonic foraminiferal biostratigraphy. Proceedings of the
First International Conference on Planktonic Microfossils, 199-422.

Boersma, A. 1978. Foraminifera, Introduction to Marine Micropaleontology. Elsevier North Holland Inc., Amsterdam.

Bolli, H.M. and Saunders,J.B. 1985. Oligocene to Holocene low latitude planktonic foraminifera, p. 155-257. In Bolli, H.M., Saunders, J.B., and Perch-Nielsen, K. (eds.), Plankton Stratigraphy. Cambridge University Press, New York.

Brasier, M.D. 1980. Microfossils. University of Hull Press, Kingston-upon-Hull, UK.

Corredor, F., John, H.S., and Frank, B. 2005. Structural Styles in the deep-water fold and thrust belts of the Niger Delta. American Association of Petroleum Geologists Bulletin, 89(6):753-780.

Evamy, D.D.J., Haremboure, P., Kamerling, W.A., Knaap, F., Molloy, A., and Rowlands, M.H. 1978. Hydrocarbon habitat of the Tertiary Niger Delta. American Association of Petroleum Geologists Bulletin, 62:1-39.

Funnel, B.M. 1967. Foraminifera and radiolarian as depth indicators in the marineenvironment. Marine Geology, 5:333-347.

Haq, B.U., Hardenbol, J., and Vail, P.R. 1988. Mesozoic and Cenozoic chronostratigraphy and cycles of sealevel change, p. 71-108. In Wilgus, C.K., Hastings, B.S., Ross, C.A., Posamentier, H., Van Wagoner, J.C., and St. C. Kendall, C.G. (eds.), Sea Level Changes: An Integrated Approach. SEMP special publication 42, SEPM, Tulsa, Oklahoma, USA.

Hedberg, H.D. 1976. International Stratigraphic Guide A Guide to Stratigraphic Classification, Terminology, and Procedure. John Wiley and Sons, New York.

Loeblich, A.R., Jr. and Tappan, H. 1987. Foraminifera and Their Classification. Van Nostrand Reinhold Company, New York.

Murat, R.C. 1972. Stratigraphy and paleogeography of the Cretaceous and Lower Tertiary in Southern Nigeria, p. 251-266. In Dessauvagie, T.F.J. and Whiteman, A.J. (eds.), African Geology. Ibadan University Press, Ibadan, Nigeria.

Murray, J.W. 1973. Distribution and Ecology of Living Benthic Foraminiferids. Crane, Russak and Co., New York.

Murray, J.W. 1991. Ecology and Paleoecology of Benthic Foraminifera. John Willey and Sons Inc.,New York.

Nagy, J., Løfadli, M., and Bäckström, S.A. 1988. Aspects of Foraminiferal Distribution and Depositional Conditions in Middle Jurassic to Early Cretaceous Shales in Eastern Spitsbergen. Abhandlungen der Geologischen Bundesanstalt Wien, 41:287-300.

Nton, M.E. and Esan, T.B. 2010. Sequence stratigraphy of EMI field, offshore Eastern Niger Delta, Nigeria. European Journal of Scientific Research, 44(1):115132.

Obiosio, E.O. 2013. Biostratigraphy and paleoenvironment of Bolivina fauna from the Niger Delta, Nigeria.Earth Science Research, 2(2):80-90. 
Oboh-lkuenobe, F.E., Obi, C.G., and Jaramillo, C.A. 2005. Lithofacies, palynofacies and sequence stratigraphy of palaeogene strata in southeastern Nigeria. Journal of African Earth Sciences, 41:79-101.

Okosun, E.A., Chukwu, J.N., Ajayi, E.G., and Olatunji, O.A. 2012. Biostratigraphy, depositional environment and sequence stratigraphy of Akata Field (Akata 2, 4, 6 and 7 Wells), Eastern Niger Delta, Nigeria. International Journal of Scientific \& Engineering Research, $3(7): 1-27$

Oloto, I.N. and Promise, W. 2014. Biostratigraphic study and paleoenvironmental reconstruction of cores from offshore (South Western) Niger Delta, Nigeria. International Journal of Scientific and Technology Research, 3(2):219-286.

Oluwatosin, J.R. 2010. Sequence stratigraphy study within a chronostratigraphic framework of 'Ningning field', Niger Delta. RMZ -Materials and Geoenvironment, 57:475-500.

Ozumba, M.B. and Amajor, L.C. 1999. Evolutionary relationships in some benthonic foraminifera of the Middle to Late Miocene, Niger Delta. Nigerian Association of Petroleum Explorationist Bulletin, 14(2):157-167.

Pessagno, E.A., Jr. 1967. Upper Cretaceous planktonic foraminifera from the West Coastal Plain. Palaeontographia Americana, 5:259-441.

Petters, S.W. 1979. Nigerian Paleocene benthonic foraminiferal biostratigraphy, paleoecology and paleobiologeography. Marine Micropaleontology, 4(1):85-99.

Petters, S.W. 1982. Central West African CretaceousTertiary benthic foraminifera and stratigraphy. Palaeontographica Abteilung A, 179:1-104.
Petters, S.W. 1983. Gulf of Guinea planktonic foraminiferal biochronology and geological history of the South Atlantic. Journal of Foraminiferal Research, 13:32-59.

Reijers, T.J.A., Petters, S.W., and Nwajide, C.S. 1997. The Niger Delta Basin, p. 145-168. In Selley, R.C. (ed.), Sedimentary Basins of the World, Vol. 3, African Basins. Elsevier, Amsterdam.

Sellier de Civrieux, J.M. 1976. Estudiosistematico y ecologico de las Bolivinitidaerecientes de Venezuela. Cuadernos Oceanográfico, 5:3-101.

Sen Gupta, B.K. 1999. Systematics of modern Foraminifera, p. 7-36. In Sen Gupta, B.K. (ed.), Modern Foraminifera. Kluwer Academic Publishers, Dordrecht, Netherlands.

Short, K.C. and Stauble, A.J. 1967. Outline geology of the Niger Delta. American Association of Petroleum Geologists Bulletin, 51:761-779.

Urhobo Historical Society. A Map of Delta State, Nigeria, showing Urhobo land and other ethnicnationalities. www.waado.org/nigerdelta/maps/deltastate/delta_state_ethnic:html

Weber, K.J. and Daukoru, E. 1975. Petroleum geology of the Niger Delta. Ninth World Petroleum Congress Tokyo Proceedings, 2:209-221.

Whiteman, A. 1982. Nigeria: Its Petroleum Geology, Resources and Potential. Graham and Trotman Ltd., London.

Zingula, R.P. 1968. A new breakthrough in sample washing. Journal of Paleontology, 42(4):1092. 
NWAEJIJe, Obiosio, \& Hamidu: ForaminifERA IN Niger DELTA

\section{APPENDIX 1.}

Planktonic foraminifera count.

\begin{tabular}{|c|c|c|c|c|c|c|c|c|c|c|c|c|c|c|c|c|}
\hline Formation & Age & $\begin{array}{l}\text { Samples } \\
\text { (Metres) }\end{array}$ & 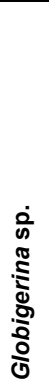 & 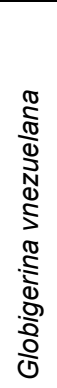 & 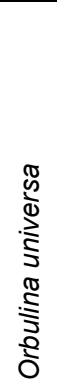 & 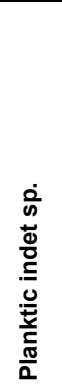 & 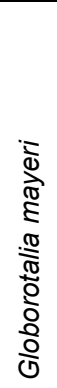 & 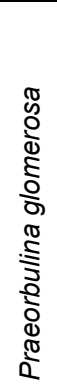 & 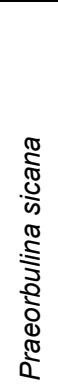 & 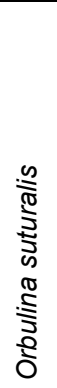 & 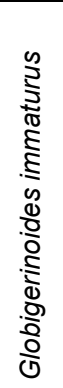 & 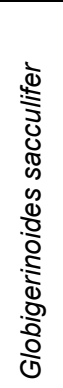 & 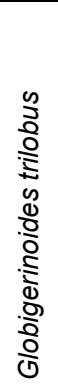 & 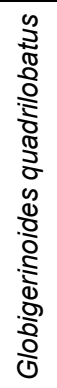 & 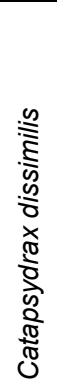 & 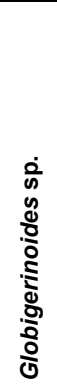 \\
\hline \multirow[t]{30}{*}{ Agbada Formation } & & 2441 & & & & & & & & & & & & & & \\
\hline & & 2460 & & & & & & & & & & & & & & \\
\hline & & 2478 & & & & & & & & & & & & & & \\
\hline & & 2496 & & & & & & & & & & & & & & \\
\hline & & 2515 & & & & & & & & & & & & & & \\
\hline & & 2533 & & & & & & & & & & & & & & \\
\hline & & 2551 & & & & & & & & & & & & & & \\
\hline & & 2569 & & & & & & & & & & & & & & \\
\hline & & 2588 & & & & & & & & & & & & & & \\
\hline & Middle Miocene & 2606 & & & & & & & & & & & & & & \\
\hline & & 2624 & 1 & & & & & & & & & & & & & \\
\hline & & 2643 & & 1 & 1 & 1 & & & & & & & & & & \\
\hline & & 2661 & & & & & 1 & & & & & & & & & \\
\hline & & 2679 & & & & & & 1 & & & & & & & & \\
\hline & & 2697 & 1 & & & & & & & & & & & & & \\
\hline & & 2716 & & & & & & & & & & & & & & \\
\hline & & 2734 & & & & & & & & & & & & & & \\
\hline & & 2752 & & 1 & & & 1 & & & & & & & & & \\
\hline & & 2771 & & & & & & & & & & & & & & \\
\hline & & 2789 & & & & & & & & & & & & & & \\
\hline & & 2807 & & & & & & & & & & & & & & \\
\hline & & 2825 & & & & & & & & & & & & & & \\
\hline & & 2844 & & & & & & & & & & & & & & \\
\hline & & 2862 & & & & & & & & & & & & & & \\
\hline & & 2880 & & & & & & 1 & 1 & & & & & & & \\
\hline & & 2899 & & & & & & & & & & & & & & \\
\hline & & 2917 & & & & & & & & & & & & & & \\
\hline & & 2935 & & & & & & & & & & & & & & \\
\hline & & 2954 & & & & & & & & & & & & & & \\
\hline & & 2972 & & & & & & & & & & & & & & \\
\hline \multirow[t]{4}{*}{ Agbada Formation } & & 2990 & & & & & & & & & & & & & & \\
\hline & & 3008 & & & & & & & & & & & & & & \\
\hline & & 3027 & & & 1 & & & & 1 & 1 & & & & & & \\
\hline & $\begin{array}{l}\text { Early - Middle } \\
\text { Miocene }\end{array}$ & 3045 & & & & & & & & & & & & & & \\
\hline
\end{tabular}




\begin{tabular}{|c|c|c|c|c|c|c|c|c|c|c|c|c|c|c|c|c|}
\hline Formation & Age & $\begin{array}{l}\text { Samples } \\
\text { (Metres) }\end{array}$ & 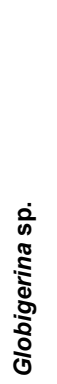 & 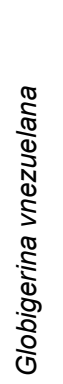 & 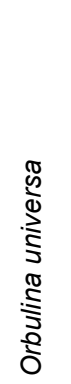 & 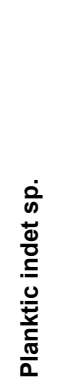 & 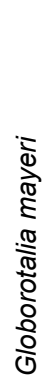 & 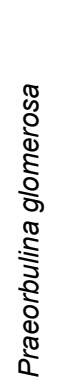 & 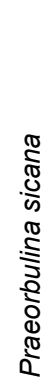 & 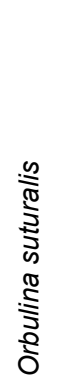 & 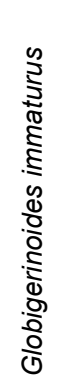 & 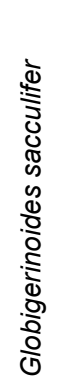 & 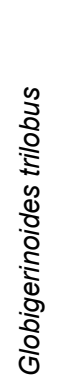 & 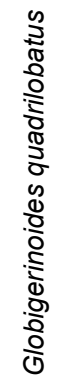 & 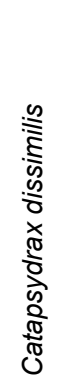 & 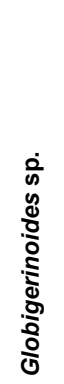 \\
\hline & & 3063 & & & & & & & & 2 & 1 & 1 & 1 & & & \\
\hline & & 3082 & & & & & & & & & & & & & & \\
\hline & & 3100 & & & & & & & & & & & & & & \\
\hline & & 3118 & & & & 1 & & & & & & & & & & \\
\hline & & 3136 & & & & & & & & & & & & & & \\
\hline & & 3155 & & & & & & & & & & & & & & \\
\hline & & 3173 & & & & & & & & & & & & & & \\
\hline & & 3191 & & & & & & & & & & & & & & \\
\hline & & 3210 & & & & & & & & & & & & & & \\
\hline & & 3228 & & & & & & & & & & & & & & \\
\hline & & 3246 & & & & & & & & & & & & & & \\
\hline & & 3264 & & & & & & & & & & & & & & \\
\hline & & 3283 & & & & & & & & & & & & & & \\
\hline & & 3301 & & & & & & & & & & & & & & \\
\hline & & 3319 & & & & & & & & & & & & & & \\
\hline & & 3338 & & & & & & & & & & & & & & \\
\hline & & 3356 & & & & & & & & & & & & & & \\
\hline & & 3374 & 1 & & & & & & & 1 & & & & & & \\
\hline & & 3392 & & & & & & & & & & & & & & \\
\hline & & 3411 & & & & & & 1 & & & & & & & & \\
\hline & Early Miocene & 3429 & & & & & & & & & & & & & & \\
\hline & & 3447 & & & & & & & & & & & & & & \\
\hline & & 3466 & & & & & & & & & & & & & & \\
\hline & & 3484 & & & & & & & & & & & & & & \\
\hline & & 3502 & 1 & & & & & & & & & & & & & \\
\hline & & 3520 & & & & & & & & & & & & & & \\
\hline & & 3539 & & & & & & & & & & & & & & \\
\hline & & 3557 & & & & & & & & & & & & & & \\
\hline & & 3575 & & & & & & & & & & & & & & \\
\hline \multirow[t]{4}{*}{ Agbada Formation } & & 3594 & & & & & & & & & & & & & & \\
\hline & & 3612 & & & & 1 & & & & & & & & 1 & & \\
\hline & & 3630 & & & & & & & & & & & & & & \\
\hline & & 3648 & 1 & & & & 1 & & & & 1 & & 1 & & 1 & 1 \\
\hline
\end{tabular}


NWAEJIJE, ObIOSIO, \& HAMIdU: ForaminifERA IN Niger DELTA

APPENDIX 2.

Benthonic foraminifera count.

\begin{tabular}{|c|c|c|c|c|c|c|c|c|c|c|c|c|c|c|c|c|}
\hline Formation & Age & $\begin{array}{l}\text { Samples } \\
\text { (Metres) }\end{array}$ & 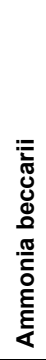 & 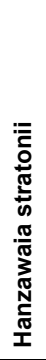 & 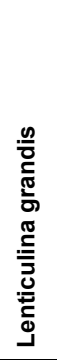 & 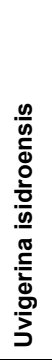 & 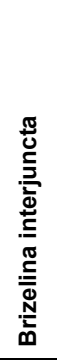 & 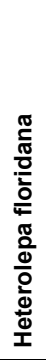 & 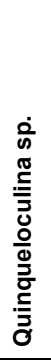 & 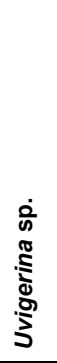 & 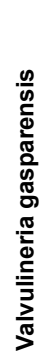 & 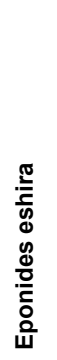 & 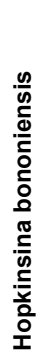 & 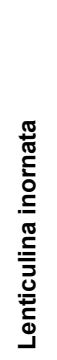 & 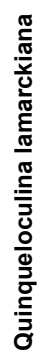 & 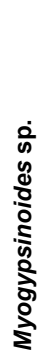 \\
\hline \multirow[t]{35}{*}{ Agbada Formation } & & 2441 & & & & & & & & & & & & & & \\
\hline & & 2460 & & & & & & & & & & & & & & \\
\hline & & 2478 & & & & & & & & & & & & & & \\
\hline & & 2496 & & & & & & & & & & & & & & \\
\hline & & 2515 & & & & & & & & & & & & & & \\
\hline & & 2533 & & & & & & & & & & & & & & \\
\hline & & 2551 & & & & & & & & & & & & & & \\
\hline & & 2569 & & & & & & & & & & & & & & \\
\hline & & 2588 & & & & & & & & & & & & & & \\
\hline & Middle Miocene & 2606 & & & & & & & & & & & & & & \\
\hline & & 2624 & 1 & 1 & 1 & 2 & & & & & & & & & & \\
\hline & & 2643 & 2 & & 5 & 8 & 1 & 6 & 2 & 1 & 1 & & & & & \\
\hline & & 2661 & 2 & & 6 & 6 & & 2 & 2 & & 1 & 1 & 1 & 1 & 1 & \\
\hline & & 2679 & 3 & 2 & 1 & 7 & 1 & & & 2 & 1 & & & & & 1 \\
\hline & & 2697 & & 1 & & 3 & & & & 2 & & 1 & & & & 1 \\
\hline & & 2716 & & & & & & & & 1 & & & & & & \\
\hline & & 2734 & 2 & 1 & & & & & & 1 & & & & & & \\
\hline & & 2752 & & & & 1 & & 1 & 1 & & & & & & & \\
\hline & & 2771 & & 1 & & & & & & & & & & & & \\
\hline & & 2789 & & & & & & & & & & & & & & \\
\hline & & 2807 & & & & & & & & & & & & & & \\
\hline & & 2825 & & & & & & & & & & & & & & \\
\hline & & 2844 & & & & & & & & & & & & & & \\
\hline & & 2862 & & & & & & & & & & & & & & \\
\hline & & 2880 & & & & & & & & & & & & & & \\
\hline & & 2899 & & & & & & & & & & & & & & \\
\hline & & 2917 & & & & & & & & & & & & & & \\
\hline & & 2935 & & & & & & & & & & & & & & \\
\hline & & 2954 & & & & & & & & & & & & & & \\
\hline & & 2972 & & & & & & & & & & & & & & \\
\hline & & 2990 & & & & 1 & & & & & & & & & & \\
\hline & & 3008 & & & 1 & 1 & & & & & & & & & & \\
\hline & & 3027 & & & & & & & & & & & 1 & & & \\
\hline & $\begin{array}{l}\text { Early - Middle } \\
\text { Miocne }\end{array}$ & 3045 & & & & & & & & & & & & & & \\
\hline & & 3063 & 1 & 7 & & & & 4 & & 4 & 2 & & 6 & & & \\
\hline
\end{tabular}




\begin{tabular}{|c|c|c|c|c|c|c|c|c|c|c|c|c|c|c|c|c|}
\hline Formation & Age & $\begin{array}{l}\text { Samples } \\
\text { (Metres) }\end{array}$ & 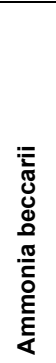 & 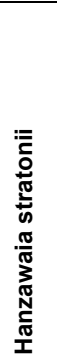 & 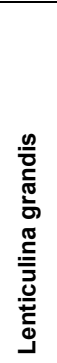 & 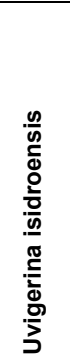 & 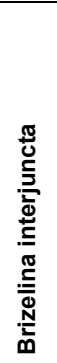 & 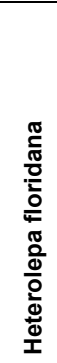 & 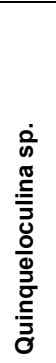 & 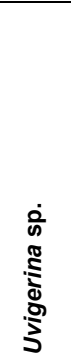 & 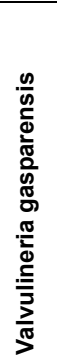 & 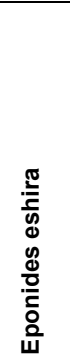 & 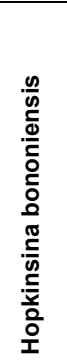 & 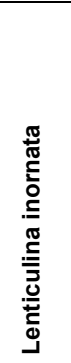 & 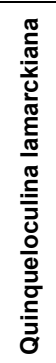 & 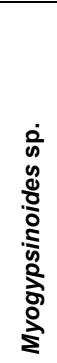 \\
\hline \multirow[t]{32}{*}{ Agbada Formation } & & 3082 & & & & & & & & & & & & & & \\
\hline & & 3100 & & & & & & & & & & & & & & \\
\hline & & 3118 & & & & & & & & & & & & & & \\
\hline & & 3136 & & & & & & & & & & & & & & \\
\hline & & 3155 & & & & & & & & & & & & & & \\
\hline & & 3173 & & & & & & & & & & & & & & \\
\hline & & 3191 & & & & & & & & & & & & & & \\
\hline & & 3210 & & & & & & & & & & & & & & \\
\hline & & 3228 & & & & & & & & & & & & & & \\
\hline & & 3246 & & & & & & & & & & & & & & \\
\hline & & 3264 & & & & & & & & & & & & & & \\
\hline & & 3283 & & & & & & & & & & & & & & \\
\hline & & 3301 & & & & & & & & & & & 1 & & & \\
\hline & & 3319 & & & & & & 1 & & & & & & & & \\
\hline & & 3338 & & 1 & 9 & 19 & 4 & & 1 & & 2 & & 4 & & & \\
\hline & & 3356 & & & 1 & & & & & & & & & & & \\
\hline & & 3374 & & 1 & & 1 & & & & & 2 & & & 1 & & \\
\hline & & 3392 & & & & & & & & & & & & & & \\
\hline & & 3411 & & & & 6 & & & & & & & & & & \\
\hline & Early Miocene & 3429 & & & 1 & 5 & & & & & & 2 & & & & \\
\hline & & 3447 & & & & & & & & & & & & & & \\
\hline & & 3466 & & & & & & & & & & & & & & \\
\hline & & 3484 & & & & & & & & & & & & & & \\
\hline & & 3502 & & & & & & & & & & & & & & \\
\hline & & 3520 & & & & & & & & & & & & & & \\
\hline & & 3539 & & & 1 & & & & & & & & & & & \\
\hline & & 3557 & 1 & & 1 & 6 & 2 & & & & & 1 & 7 & & & \\
\hline & & 3575 & & & & & & & & & & & & & & \\
\hline & & 3594 & & & & & & & & & & & & & & \\
\hline & & 3612 & & & & & & & & & & & & & & \\
\hline & & 3630 & & & 5 & & & & & 2 & & & & & & 2 \\
\hline & & 3648 & 2 & 6 & 4 & 31 & & 4 & & & 1 & 3 & 13 & 1 & & 1 \\
\hline
\end{tabular}

